\title{
A comparative study of the work-family conflicts prevalence, its sociodemographic, family, and work attributes, and its relation to the self- reported health status in Japanese and Egyptian civil workers
}

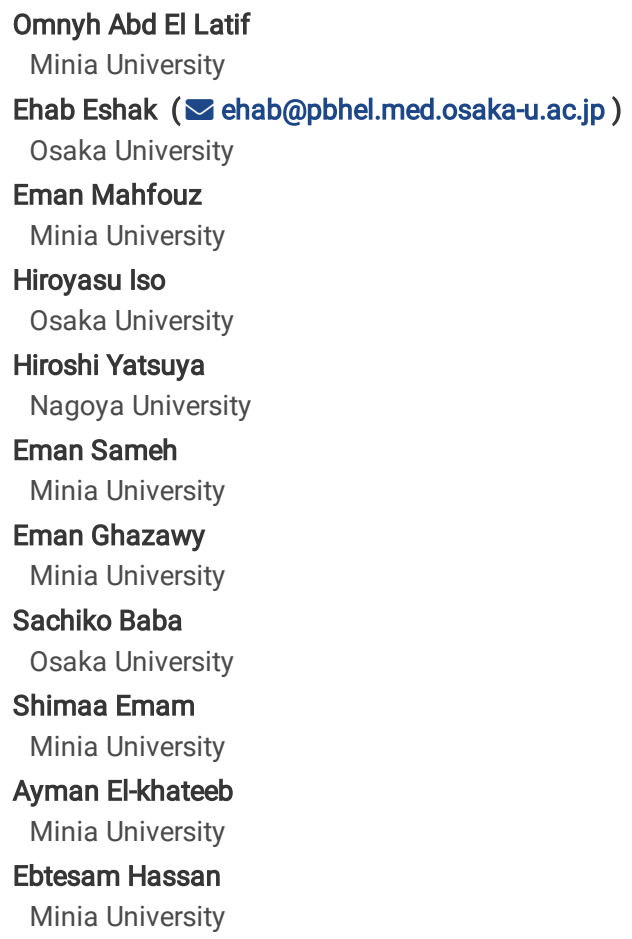

Research Article

Keywords: Cross-cultural study, work-family conflict, self-rated health, gender, civil workers, Japan, Egypt

Posted Date: October 12th, 2021

DOI: https://doi.org/10.21203/rs.3.rs-955067/v1

License: @ (i) This work is licensed under a Creative Commons Attribution 4.0 International License. Read Full License 


\section{Abstract \\ Background}

Cross-cultural studies studying work-family conflicts (W_F_Cs) are scarce. We compared the prevalence of W_F_Cs, factors predicting it, and its association with self-rated health between Japan and Egypt.

\section{Methods}

Among 4862 Japanese and 3111 Egyptian civil workers who were recruited by a convenience sample in 2018/2019 and reported self-rated health status, we assessed the W_F_Cs by the Midlife Development in the US (MIDUS) and attributed it, by linear regression analyses, to sociodemographic, family, and work variables, and assessed its gender- and country-specific associations with self-rated health by logistic regression analyses.

\section{Results}

W_F_Cs were more prevalent in Egyptian than Japanese women ( $23.7 \%$ vs. $18.2 \%)$ and men (19.1\% vs. $10.5 \%)$, while poor self-rated health was more prevalent in Japanese than Egyptians (19.3\% and $17.3 \%$ vs. $16.9 \%$ and $5.5 \%)$. In both genders of countries, longer working hours, shift work, and overtime work predicted higher scores of the work-to-family conflict (WFC). In contrast, single status predicted lower scores of the family-to-work conflict (FWC). Living with children, fathers, or alone in Japan, while education in Egypt was associated with the conflicts. The OR (95\% Cl) for poor self-reported health among those with the strong, in reference to weak W_F_Cs, was 4.28 (2.91-6.30) and 6.01 (4.50-8.01) in Japanese women and men and was 2.46 (1.75-3.47) and 3.11 (1.675.80) in Egyptian women and men.

\section{Conclusions}

Japanese and Egyptian civil workers have different prevalence and correlated factors of W_F_Cs and self-rated health. W_F_Cs were associated in a doseresponse pattern with poor-self-rated health civil workers of both countries.

\section{Introduction}

Work and family are key realms of human life. However, sometimes the individuals' time, strain, and behavior related to one realm clash with those of the other [1]. Unfair distribution of the subject's energy and time could lead to some sort of conflict [2]. This conflict could be directed from work to family and described as work-to-family conflict (WFC) or from family to work and described as family-to-work conflict (FWC) [3]. Both WFC and FWC compose the total work-family conflicts (W_F_Cs) [4, 5]. Khan et al. (1964) have defined W_F_Cs as "inter-role conflicts in which the role pressures from the work and family domains are mutually incompatible in some respect" [6].

W_F_Cs have become a rich area for organizational, social, and health research because they influence organizational achievement [7] and workers' personal lives [8, 9]. W_F_Cs have been related to absenteeism, tardiness, leaving work early, turnover intentions, and other negative work behaviors [10]. Meanwhile, W_F_Cs have been associated with adverse physical and mental health outcomes $[9,11,12]$.

The World Health Organization (WHO) suggested in the early 1990s the implementation of self-rated health as a valuable tool for assessing individuals' health and quality of life [13]. Since then, self-rated health was widely used in social science research.

So far, there is a considerable bulk of research studied the attributes of W_F_Cs [14-18] and linked W_F_Cs to poor self-rated health of community dwellers [8, $11]$ and working populations [12,19-21]. The literature indicated vast variabilities in the W_F_Cs' levels and their correlates, the proportions of subjects with poor self-rated health, and the magnitude of association between these conflicts and self-rated health across different cultures and populations. Yet, crosscultural studies that compare the attributes and the health sequences of W_F_Cs among working people of different cultures are limited [5]. In Egypt and Japan, the released literature was based on small sample studies and indicated social and occupational variabilities between the two populations, such as the differences in the family structure and the average daily working hours. Yet, the two countries are alike in the lifetime-employment system and the community's view of males as breadwinners and females as caregivers. The Egyptian studies suggested the prevalence of WFC, FWC, and poor self-rated health as $46.7 \%, 50.8 \%$, and $16.9 \%$ [11]. The prevalence reported in the Japanese studies ranged between $15.2-54.0 \%$ for WFC, 21.2 to $36.4 \%$ for FWC, and $13.9-35.2 \%$ for poor self-rated health in men and $22.8-72.5 \%, 16.3-56.8 \%$, and $17.7-36.0 \%$, respectively in women [8, 12, 17]. Accordingly, in the current research, we aimed to run a cross-cultural study among large samples of Egyptian and Japanese civil workers to compare the prevalence and correlated factors of the W_F_Cs and poor self-rated health in the two working populations and to compare the associations of W_F_Cs with the poor self-rated health among the civil workers in both countries.

\section{Methods}

\section{Subjects}

This comparative, cross-cultural study data were collected separately for Japanese and Egyptian civil workers who work in a central prefecture/governorate (Aichi in Japan and Minia in Egypt). A total of 5310 civil workers aged 20-60 years responded to the 2018 data collection cycle of the Aichi Workers' Cohort 
study, and 3133 Egyptian civil workers of the same age range responded to the Minia University Public Health Department's survey in 2019. The Aichi Workers' Cohort study [22] and the Egyptian survey were published previously [23]. As we aim to study the work and family interface, we excluded civil workers who reported the number of family members $=0$; thus, the final sample consisted of 4862 Japanese and 3111 Egyptian civil workers. The ethical review boards in Nagoya University, Japan, and Minia University, Egypt, have approved each survey. The ethical review board in [Masked for Review] (which hosted the Japanese and Egyptian collected data) has also approved the comparative study (approval no 19501). All Egyptian participants consented to provide their data for the comparative research, and Japanese participants who did not respond to an opt-out consent were considered agreeing to be involved in the comparative study.

\section{Data}

The self-administered questionnaire used in both countries contained the same set of targeted variables, including information on the civil workers' sociodemographic, family, job, and health aspects.

\section{Work-family conflicts}

The following four statements were used to investigate the level of FWC, 1- "Thinking about home troubles can confuse you at work," 2-"The work time is reduced due to home-related issues," 3- "Your own time to relax is reduced due to responsibilities at home," and 4- "Due to housework, you cannot have enough sleeping time you need to accomplish your work." The following four statements were used to investigate the level of work-to-family conflict (WFC), 1"Work problems make you annoyed at home," 2-“I dedicate less time to my family because I have to work," 3-"My work depletes my energy that I feel not able to pay attention to anything at home," and 4- "I am often out of home for a long time due to work needs." For each statement, participants can choose one frequency response on a three-point Likert scale ( $0=$ never, $1=$ to some extent, $2=$ often/ very often) as initially indicated by the Midlife Development in the United States National Study [24] and used in previous Japanese [8] and Egyptian [25] settings.

Health status (Self-reported).

The participants were asked to choose either " $1=$ very good, $2=$ fairy good, $3=$ good, $4=$ not very good, $5=$ not good" in response to the question "How do you rate your current physical health status?". Participants who chose "not very good" and "not good" were considered to have a poor self-reported health status.

\section{Other variables}

We collected information on the sociodemographic, family, and work attributes of the participants, which we believe it could relate to the W_F_Cs, such as age, gender, marital status, education, occupation, living arrangement, number of family members, and how many of them were under the age of 14 years, the number of average working hours per day, working overtime or additional job, time for one-way commuting to work, and whether the work is a regular day time work or requires night shifts. We also assisted the participants' lifestyle variables by inquiring about their smoking and drinking habits and measured the physical activity in the metabolic equivalent of task (METs) unit according to the self-reported hours spent in different activities.

\section{Statistical analysis}

We showed the descriptive analyses of the collected data, gender-specific to each country, as mean (SD) or proportion, and included the frequency responses to each statement of the FWC and WFC. The FWC and FWC ranged between 0 and 8 points and joined into a 0 to 16 points score to represent the total W_F_Cs as indicated by previous studies [4, 5, 25]. We used the continuous scores of FWC, WFC, and W_F_Cs as our dependent variable in the multiple linear regression analyses to assess the following:-

1- Which sociodemographic, family, and work factors are associated with these conflicts in both populations.

2- Whether the associated variables differ by gender and country, and what the contribution of each factor is in predicting the conflicts in each gender and population.

Moreover, we used the logistic regression analyses to assess the gender-and country-specific associations of the different levels of FWC and WFC [weak conflict level (<2 points), fair conflict level (2-4 points), and strong conflict level ( $\geq 5$ points)] with the self-reported physical health status. Participants should have been ranked strong in at least one form of conflict (FWC and/or WFC) while ranked fair in the other form of conflict to be in the strong total W_F_Cs category. On the other hand, participants should have been ranked weak in at least one form of conflict while ranked fair in the other form of conflict to be in the weak total W_F_Cs category. Other than these, participants were ranked fair in the total W_F_Cs. The logistic regression models were adjusted for those mentioned above sociodemographic, family, and work factors. We computed the odds ratios (ORs) and $95 \%$ confidence intervals (Cls) of having poor selfreported health across the increasing categories of the conflicts, using the weak category as the reference group.

We used the SAS software version 9.4 (SAS Institute Inc, Cary, NC, USA) for the analyses considering a two-tailed p-value $<0.05$ for statistical significance.

\section{Results}

\section{Descriptive analyses in Tables 1 and 2}


Table 1

Descriptive analyses of the study variables among Japanese and Egyptian civil workers

\begin{tabular}{|c|c|c|c|c|}
\hline & \multicolumn{2}{|l|}{ Japan } & \multicolumn{2}{|l|}{ Egypt } \\
\hline & Women & Men & Women & Men \\
\hline Age, years ${ }^{1}$ & $38.8(11.0)$ & $44.2(10.8)$ & $38.4(10.1)$ & $43.3(10.3)$ \\
\hline Education & $80(5.0)$ & $201(6.1)$ & 218 (13.5) & $383(25.6)$ \\
\hline Junior high/High & $501(31.4)$ & $217(6.7)$ & 305 (18.9) & $354(23.6)$ \\
\hline Vocational & $1013(63.6)$ & 2847 (87.2) & $1091(67.6)$ & $760(50.8)$ \\
\hline \multicolumn{5}{|l|}{ University or more } \\
\hline Marital status & $925(58.1)$ & 2454 (75.2) & 1258 (77.9) & $1353(90.4)$ \\
\hline Married & $77(4.8)$ & $68(2.1)$ & $42(2.6)$ & $12(0.8)$ \\
\hline Divorced/Separated & $13(0.8)$ & $17(0.5)$ & 79 (4.9) & $10(0.7)$ \\
\hline Widow & $578(36.3)$ & 725 (22.2) & $235(14.6)$ & $122(8.2)$ \\
\hline \multicolumn{5}{|l|}{ Single } \\
\hline Cohabitants & 905 (56.7) & $2428(74.3)$ & $1210(75.0)$ & $1283(85.7)$ \\
\hline Spouse & 707 (44.3) & $1895(58.0)$ & 1123 (69.6) & $1212(81.0)$ \\
\hline Children & $394(24.7)$ & $622(19.0)$ & $232(14.4)$ & $250(16.7)$ \\
\hline Father & 500 (31.3) & $851(26.1)$ & $292(18.1)$ & $334(22.3)$ \\
\hline Mother & $275(17.2)$ & $295(9.0)$ & $126(7.8)$ & $87(5.8)$ \\
\hline Others & $176(11.0)$ & $248(7.6)$ & $10(0.6)$ & $13(0.8)$ \\
\hline \multicolumn{5}{|l|}{ Alone } \\
\hline Number of family members ${ }^{1}$ & $2.2(1.4)$ & $2.4(1.4)$ & $3.1(1.9)$ & $3.9(1.8)$ \\
\hline Number of children $<14$ years old ${ }^{1}$ & $0.7(0.9)$ & $0.7(0.9)$ & $1.1(1.2)$ & $1.4(1.4)$ \\
\hline Occupation & $861(54.0)$ & $1424(43.6)$ & $1070(66.3)$ & $715(47.8)$ \\
\hline Professional & $735(46.0)$ & $1842(56.4)$ & $374(23.2)$ & $521(34.8)$ \\
\hline Cleric & - & $\longrightarrow$ & $170(10.5)$ & $260(17.4)$ \\
\hline \multicolumn{5}{|l|}{ Technical/worker } \\
\hline Regular daytime work & $1201(75.4)$ & $2977(91.2)$ & $1352(83.8)$ & $1165(77.8)$ \\
\hline Yes & $392(24.6)$ & $286(8.8)$ & $262(16.2)$ & $332(22.2)$ \\
\hline \multicolumn{5}{|l|}{ No } \\
\hline Job hours per day ${ }^{1}$ & $8.2(1.3)$ & $8.4(1.1)$ & $6.8(1.5)$ & $7.5(1.7)$ \\
\hline Time to reach work, minutes ${ }^{1}$ & $45.8(24.0)$ & $56.4(26.2)$ & $30.0(21.7)$ & $31.1(21.0)$ \\
\hline Working overtime/Extra job & $1394(87.3)$ & $2797(85.6)$ & $1396(86.5)$ & $827(55.2)$ \\
\hline No & $202(12.7)$ & $469(14.4)$ & $218(13.5)$ & $670(44.8)$ \\
\hline \multicolumn{5}{|l|}{ Yes } \\
\hline Family-to-work conflict (FWC) & $746(46.7)$ & $1874(57.4)$ & $690(42.8)$ & $773(51.6)$ \\
\hline Weak (score <2) & $611(38.3)$ & 1137 (34.8) 255 (7.5) & $717(44.4)$ & $577(38.6)$ \\
\hline Fair (score 2-4) & $239(15.0)$ & $1.6(1.9)$ & $207(12.8)$ & $147(9.8)$ \\
\hline Strong $(>=5)$ & $2.2(2.1)$ & & $3.1(2.1)$ & $2.6(2.1)$ \\
\hline Family-to-work conflict score ${ }^{1}$ & & & & \\
\hline
\end{tabular}

${ }^{1}$ Mean (SD), all such variables. Other variables in the table were presented as number (proportion). 


\begin{tabular}{|c|c|c|c|c|}
\hline & \multicolumn{2}{|l|}{ Japan } & \multicolumn{2}{|l|}{ Egypt } \\
\hline & Women & Men & Women & Men \\
\hline Work-to-family conflict (WFC) & $562(35.2)$ & $1428(43.7)$ & $557(34.5)$ & $563(37.6)$ \\
\hline Weak (Score<2) & $835(52.3)$ & $1593(48.8)$ & $664(41.1)$ & $592(39.6)$ \\
\hline Fair (score 2-4) & 199 (12.5) $2.3(1.8)$ & $245(7.5) 2.0(1.7)$ & $393(24.4)$ & $342(22.8)$ \\
\hline $\begin{array}{l}\text { Strong }(>=5) \\
\text { Work-to-family conflict score }^{1}\end{array}$ & & & $3.7(2.4)$ & $3.5(2.4)$ \\
\hline Total work-family conflicts (W_F_Cs) & $859(53.8)$ & $2103(64.4)$ & $752(46.6)$ & $787(52.6)$ \\
\hline Weak & $447(28.0)$ & $821(25.1)$ & $479(29.7)$ & $424(28.3)$ \\
\hline Fair & $290(18.2)$ & $342(10.5) 3.6(3.0)$ & $383(23.7)$ & $286(19.1)$ \\
\hline Strong & $4.5(3.3)$ & & $6.8(3.7)$ & $6.1(3.8)$ \\
\hline \multicolumn{5}{|l|}{ Total work-family conflict score ${ }^{1}$} \\
\hline Self-reported health & 1288 (80.7) 308 (19.3) & $2703(82.8)$ & $1341(83.1)$ & $1414(94.5)$ \\
\hline Good & & $563(17.3)$ & $273(16.9)$ & $83(5.5)$ \\
\hline Poor & & & & \\
\hline
\end{tabular}


Table 2

Comparing the response frequency to the work-family conflict items in Japanese and Egyptian civil workers

\begin{tabular}{|c|c|c|c|c|c|c|}
\hline & \multicolumn{3}{|l|}{ Japan } & \multicolumn{3}{|l|}{ Egypt } \\
\hline & Never & Sometimes & Often & Never & Sometimes & Often/always \\
\hline \multicolumn{7}{|l|}{ Women } \\
\hline \multicolumn{7}{|l|}{ Family-to-work conflict (FWC) } \\
\hline "Thinking about home troubles can confuse you at work" & $\begin{array}{l}1006 \\
(63.0)\end{array}$ & $488(30.6)$ & $\begin{array}{l}102 \\
(6.4)\end{array}$ & $\begin{array}{l}1045 \\
(64.7)\end{array}$ & $443(27.5)$ & $126(7.8)$ \\
\hline "The work time is reduced due to home-related issues" & $\begin{array}{l}944 \\
(59.1)\end{array}$ & $595(37.3)$ & $\begin{array}{l}57 \\
(3.6)\end{array}$ & $\begin{array}{l}711 \\
(44.0)\end{array}$ & $684(42.4)$ & $219(13.6)$ \\
\hline "Your own time to relax is reduced due to responsibilities at home" & $\begin{array}{l}847 \\
(53.0)\end{array}$ & $566(35.5)$ & $\begin{array}{l}183 \\
(11.5)\end{array}$ & $\begin{array}{l}657 \\
(40.7)\end{array}$ & $610(37.8)$ & $347(21.5)$ \\
\hline $\begin{array}{l}\text { "Due to housework, you cannot have enough sleeping time you need to } \\
\text { accomplish your work" }\end{array}$ & $\begin{array}{l}756 \\
(47.4)\end{array}$ & $542(33.9)$ & $\begin{array}{l}298 \\
(18.7)\end{array}$ & $\begin{array}{l}417 \\
(25.8)\end{array}$ & $577(35.8)$ & $620(38.4)$ \\
\hline \multicolumn{7}{|l|}{ Work-to-Family conflict (WFC) } \\
\hline "Work problems make you annoyed at home" & $\begin{array}{l}524 \\
(32.8)\end{array}$ & $734(46.0)$ & $\begin{array}{l}338 \\
(21.2)\end{array}$ & $\begin{array}{l}505 \\
(32.3)\end{array}$ & $658(40.8)$ & $451(27.9)$ \\
\hline "I dedicate less time to my family because I have to work" & $\begin{array}{l}654 \\
(41.0)\end{array}$ & $755(47.3)$ & $\begin{array}{l}187 \\
(11.7)\end{array}$ & $\begin{array}{l}451 \\
(27.9)\end{array}$ & $663(41.1)$ & $500(40.0)$ \\
\hline $\begin{array}{l}\text { "My work depletes my energy that I feel not able to pay attention to } \\
\text { anything at home" }\end{array}$ & $\begin{array}{l}1303 \\
(81.6)\end{array}$ & $279(17.5)$ & $\begin{array}{l}14 \\
(0.9)\end{array}$ & $\begin{array}{l}793 \\
(49.1)\end{array}$ & $457(28.3)$ & $364(22.6)$ \\
\hline "I am often out of home for long time due to work need" & $\begin{array}{l}844 \\
(52.9)\end{array}$ & $600(37.6)$ & $\begin{array}{l}152 \\
(9.5)\end{array}$ & $\begin{array}{l}531 \\
(32.9)\end{array}$ & $612(37.9)$ & $471(29.2)$ \\
\hline \multicolumn{7}{|l|}{ Men } \\
\hline \multicolumn{7}{|l|}{ Family-to-work conflict (FWC) } \\
\hline "Thinking about home troubles can confuse you at work" & $\begin{array}{l}2213 \\
(67.7)\end{array}$ & $949(29.1)$ & $\begin{array}{l}104 \\
(3.2)\end{array}$ & $\begin{array}{l}938 \\
(62.7)\end{array}$ & $415(27.7)$ & $144(9.6)$ \\
\hline "The work time is reduced due to home-related issues" & $\begin{array}{l}2059 \\
(63.1)\end{array}$ & $\begin{array}{l}1118 \\
(34.2)\end{array}$ & $\begin{array}{l}89 \\
(2.7)\end{array}$ & $\begin{array}{l}727 \\
(48.6)\end{array}$ & $547(36.5)$ & $223(14.9)$ \\
\hline "Your own time to relax is reduced due to responsibilities at home" & $\begin{array}{l}2383 \\
(73.0)\end{array}$ & $749(22.9)$ & $\begin{array}{l}134 \\
(4.1)\end{array}$ & $\begin{array}{l}766 \\
(51.2)\end{array}$ & $512(34.2)$ & $219(14.6)$ \\
\hline $\begin{array}{l}\text { "Due to housework, you cannot have enough sleeping time you need to } \\
\text { accomplish your work" }\end{array}$ & $\begin{array}{l}1733 \\
(53.0)\end{array}$ & $\begin{array}{l}1194 \\
(36.6)\end{array}$ & $\begin{array}{l}339 \\
(10.4)\end{array}$ & $\begin{array}{l}584 \\
(39.0)\end{array}$ & $577(38.5)$ & $336(22.5)$ \\
\hline \multicolumn{7}{|l|}{ Work-to-Family conflict (WFC) } \\
\hline "Work problems make you annoyed at home" & $\begin{array}{l}1256 \\
(38.5)\end{array}$ & $\begin{array}{l}1483 \\
(45.4)\end{array}$ & $\begin{array}{l}527 \\
(16.1)\end{array}$ & $\begin{array}{l}525 \\
(35.1)\end{array}$ & $518(34.6)$ & $454(30.3)$ \\
\hline "I dedicate less time to my family because I have to work" & $\begin{array}{l}1694 \\
(51.9)\end{array}$ & $\begin{array}{l}1368 \\
(41.9)\end{array}$ & $\begin{array}{l}204 \\
(6.2)\end{array}$ & $\begin{array}{l}556 \\
(37.1)\end{array}$ & $572(38.2)$ & $369(24.7)$ \\
\hline $\begin{array}{l}\text { "My work depletes my energy that I feel not able to pay attention to } \\
\text { anything at home" }\end{array}$ & $\begin{array}{l}2632 \\
(80.6)\end{array}$ & $598(18.3)$ & $\begin{array}{l}36 \\
(1.1)\end{array}$ & $\begin{array}{l}637 \\
(42.6)\end{array}$ & $454(30.3)$ & $406(27.1)$ \\
\hline "I am often out of home for long time due to work need" & $\begin{array}{l}1976 \\
(60.5)\end{array}$ & $\begin{array}{l}1103 \\
(33.8)\end{array}$ & $\begin{array}{l}187 \\
(5.7)\end{array}$ & $\begin{array}{l}595 \\
(39.8)\end{array}$ & $532(35.5)$ & $370(24.7)$ \\
\hline
\end{tabular}

The mean age in the Japanese cohort was 38.8 years for women and 42.4 years for men, while in the Egyptian survey was 38.4 and 43.3 years, respectively. In both countries, most of the participants were educated to a university level or above (in Japan, $63.6 \%$ of females and $87.2 \%$ of males, and in Egypt $67.6 \%$ of females and $50.8 \%$ of males), currently married ( $58.1 \%$ and $75.2 \%$ in Japan, and $77.9 \%$ and $90.4 \%$ in Egypt), and working regular daytime jobs (75.4\% and $91.2 \%$ in Japan, and $83.8 \%$ and $77.8 \%$ in Egypt). There were more singles (36.3\% females and $22.2 \%$ males) and living alone ( $11.0 \%$ females and $7.6 \%$ males) Japanese than Egyptian ( $14.6 \%$ and $8.2 \%$ single females and males, and $0.6 \%$ and $0.8 \%$ living alone females and males) civil workers. Larger families (mean family members $=3.1$ to 3.9 and mean juniors $=1.1$ to 1.4 ) were seen in Egypt than in Japan (2.2 to 2.4 and 0.7 respectively). The Japanese civil workers worked on average for 8.2 per day hours for females and 8.4 hours for males, and $12.7 \%$ and $14.4 \%$ of them worked overtime. On the other hand, the average working hours per day and the proportion of civil workers who worked additional jobs in Egypt were 6.8 hours and $13.5 \%$ for females and 7.5 hours and $44.8 \%$ for males.

Japanese women had a higher prevalence of FWC (15.0\%) than Egyptian women (12.8\%), but the opposite was found in men (7.8\% in Japanese men and $9.8 \%$ in Egyptian men). A higher prevalence of strong WFC and total W_F_Cs was seen in Egypt ( $24.4 \%$ and $23.7 \%$ respectively in women and $24.4 \%$ and $23.7 \%$, respectively in men) than in Japan ( $12.5 \%$ and $18.2 \%$, respectively in women and $7.5 \%$ and $10.5 \%$ respectively in men). 
There were always higher proportions of Egyptians selecting the highest frequency option "often" in responding to each conflict statement than the Japanese counterparties.

The prevalence of poor self-rated health among the Japanese civil workers was $19.3 \%$ in females and $17.3 \%$ in males. In contrast, the Egyptian civil workers reported a lower prevalence, $16.9 \%$ in females and $5.5 \%$ in males.

The gender-and country-specific participants' characteristics according to the categories of W_F_Cs levels are shown in Supplemental Table 1. There were significant differences in the family-related factors across increasing categories of W_F_Cs in the Japanese but not the Egyptian women and men. On the other hand, the work-related factors showed similar variations in both genders of both countries.

\section{Linear regression for factors predicting the conflicts' score in Tables 3 and 4}


Table 3

Multiple linear regression for factors associated with work-family conflict among Japanese and Egyptian female civil workers

\begin{tabular}{|c|c|c|c|c|c|c|c|c|c|c|}
\hline & \multicolumn{6}{|l|}{ Japan } & \multicolumn{4}{|l|}{ Egypt } \\
\hline & \multicolumn{2}{|c|}{$\begin{array}{l}\text { Family-to-work conflict } \\
\text { (FWC) }\end{array}$} & \multicolumn{2}{|c|}{$\begin{array}{l}\text { Work-to-family conflict } \\
\text { (WFC) }\end{array}$} & \multicolumn{2}{|c|}{$\begin{array}{l}\text { Total work-family } \\
\text { conflicts (W_F_Cs) }\end{array}$} & \multicolumn{2}{|c|}{$\begin{array}{l}\text { Family-to-work conflict } \\
\text { (FWC) }\end{array}$} & \multicolumn{2}{|c|}{$\begin{array}{l}\text { Work-to-family conflict } \\
\text { (WFC) }\end{array}$} \\
\hline & $\begin{array}{l}\text { Standardized } \\
\beta\end{array}$ & P-value & $\begin{array}{l}\text { Standardized } \\
\beta\end{array}$ & P-value & $\begin{array}{l}\text { Standardized } \\
\beta\end{array}$ & P-value & $\begin{array}{l}\text { Standardized } \\
\beta\end{array}$ & P-value & $\begin{array}{l}\text { Standardized } \\
\beta\end{array}$ & P-value \\
\hline Age & 0.05 & 0.17 & 0.08 & 0.14 & 0.07 & 0.14 & -0.11 & 0.0005 & -0.14 & $<0.0001$ \\
\hline \multirow{3}{*}{$\begin{array}{l}\text { Education, (>= } \\
\text { university ref) } \\
\text { Junior high/ } \\
\text { High } \\
\text { Vocational }\end{array}$} & -0.01 & 0.64 & 0.002 & 0.92 & -0.001 & 0.81 & -0.10 & 0.0007 & -0.07 & 0.01 \\
\hline & -0.05 & 0.12 & -0.04 & 0.16 & -0.05 & 0.07 & -0.05 & 0.11 & -0.007 & 0.81 \\
\hline & & & & & & & & & & \\
\hline \multirow{2}{*}{$\begin{array}{l}\text { Marital status, } \\
\text { (Married ref) }\end{array}$} & 0.01 & 0.83 & -0.007 & 0.90 & 0.003 & 0.05 & -0.02 & 0.51 & -0.06 & 0.85 \\
\hline & -0.05 & 0.14 & -0.04 & 0.21 & -0.05 & 0.10 & -0.06 & 0.11 & -0.05 & 0.20 \\
\hline \multirow{2}{*}{\multicolumn{11}{|c|}{$\begin{array}{l}\text { Divorced } \\
\text { Widow } \\
\text { Single }\end{array}$}} \\
\hline & & & & & & & & & & \\
\hline $\begin{array}{l}\text { Living with } \\
\text { spouse, (no } \\
\text { ref) }\end{array}$ & -0.15 & 0.10 & -0.04 & 0.71 & -0.11 & 0.22 & -0.07 & 0.27 & -0.6 & 0.29 \\
\hline \multicolumn{11}{|l|}{ Yes } \\
\hline $\begin{array}{l}\text { Living with } \\
\text { children, (no } \\
\text { ref) }\end{array}$ & 0.29 & $<0.0001$ & -0.006 & 0.91 & 0.18 & $<0.0001$ & 0.05 & 0.15 & -0.01 & 0.65 \\
\hline \multicolumn{11}{|l|}{ Yes } \\
\hline $\begin{array}{l}\text { Living with } \\
\text { father, (no ref) }\end{array}$ & -0.18 & 0.0001 & -0.24 & $<0.0001$ & -0.24 & $<0.0001$ & -0.07 & 0.10 & -0.02 & 0.64 \\
\hline \multicolumn{11}{|l|}{ Yes } \\
\hline $\begin{array}{l}\text { Living with } \\
\text { mother, (no } \\
\text { ref) }\end{array}$ & 0.11 & 0.14 & 0.08 & 0.17 & 0.10 & 0.16 & 0.05 & 0.23 & 0.07 & 0.11 \\
\hline \multicolumn{11}{|l|}{ Yes } \\
\hline $\begin{array}{l}\text { Living with } \\
\text { others, (no ref) }\end{array}$ & -0.14 & 0.0008 & -0.005 & 0.90 & -0.07 & 0.05 & 0.05 & 0.03 & 0.01 & 0.94 \\
\hline \multicolumn{11}{|l|}{ Yes } \\
\hline $\begin{array}{l}\text { Living alone, } \\
\text { (no ref) }\end{array}$ & -0.18 & $<0.001$ & -0.04 & 0.12 & -0.13 & $<0.001$ & 0.04 & 0.08 & 0.007 & 0.77 \\
\hline \multicolumn{11}{|l|}{ Yes } \\
\hline $\begin{array}{l}\text { Number of } \\
\text { family } \\
\text { members }\end{array}$ & -0.03 & 0.48 & 0.18 & 0.002 & 0.07 & 0.11 & 0.05 & 0.08 & 0.04 & 0.19 \\
\hline $\begin{array}{l}\text { Number of } \\
\text { children < } 14 \\
\text { years old }\end{array}$ & 0.21 & $<0.0001$ & 0.06 & 0.14 & 0.17 & $<0.0001$ & 0.03 & 0.35 & 0.02 & 0.58 \\
\hline $\begin{array}{l}\text { Occupation, } \\
\text { (Professional } \\
\text { ref) }\end{array}$ & -0.04 & 0.18 & -0.10 & 0.002 & -0.08 & 0.01 & -0.001 & 0.92 & -0.06 & 0.02 \\
\hline \multicolumn{11}{|l|}{ Cleric } \\
\hline \multicolumn{11}{|l|}{ Technical } \\
\hline & - & - & - & - & - & - & -0.001 & 0.97 & -0.04 & 0.17 \\
\hline
\end{tabular}

The linear regression model included all the factors in the table simultaneously. 


\begin{tabular}{|c|c|c|c|c|c|c|c|c|c|c|}
\hline & \multicolumn{6}{|l|}{ Japan } & \multicolumn{4}{|l|}{ Egypt } \\
\hline & \multicolumn{2}{|c|}{$\begin{array}{l}\text { Family-to-work conflict } \\
\text { (FWC) }\end{array}$} & \multicolumn{2}{|c|}{$\begin{array}{l}\text { Work-to-family conflict } \\
\text { (WFC) }\end{array}$} & \multicolumn{2}{|c|}{$\begin{array}{l}\text { Total work-family } \\
\text { conflicts (W_F_Cs) }\end{array}$} & \multicolumn{2}{|c|}{$\begin{array}{l}\text { Family-to-work conflict } \\
\text { (FWC) }\end{array}$} & \multicolumn{2}{|c|}{$\begin{array}{l}\text { Work-to-family conflict } \\
\text { (WFC) }\end{array}$} \\
\hline & $\begin{array}{l}\text { Standardized } \\
\beta\end{array}$ & P-value & $\begin{array}{l}\text { Standardized } \\
\beta\end{array}$ & P-value & $\begin{array}{l}\text { Standardized } \\
\beta\end{array}$ & P-value & $\begin{array}{l}\text { Standardized } \\
\boldsymbol{\beta}\end{array}$ & P-value & $\begin{array}{l}\text { Standardized } \\
\beta\end{array}$ & P-value \\
\hline $\begin{array}{l}\text { Regular } \\
\text { daytime work, } \\
\text { (Yes ref) }\end{array}$ & 0.13 & 0.64 & 0.07 & 0.02 & 0.03 & 0.32 & 0.03 & 0.36 & 0.25 & $<0.0001$ \\
\hline \multicolumn{11}{|l|}{ No } \\
\hline $\begin{array}{l}\text { Job hours per } \\
\text { day }\end{array}$ & 0.03 & 0.37 & 0.13 & $<0.0001$ & 0.05 & 0.04 & 0.04 & 0.12 & 0.12 & $<0.0001$ \\
\hline $\begin{array}{l}\text { Time to reach } \\
\text { work }\end{array}$ & -0.02 & 0.41 & 0.002 & 0.99 & 0.01 & 0.60 & 0.01 & 0.63 & 0.06 & 0.03 \\
\hline $\begin{array}{l}\text { Working } \\
\text { overtime/extra } \\
\text { job (no ref) }\end{array}$ & 0.06 & 0.04 & 0.21 & $<0.0001$ & 0.15 & $<0.0001$ & 0.12 & $<0.0001$ & 0.10 & $<0.0001$ \\
\hline Yes & & & & & & & & & & \\
\hline
\end{tabular}


Table 4

Multiple linear regression for factors associated with work-family conflict among Japanese and Egyptian male civil workers

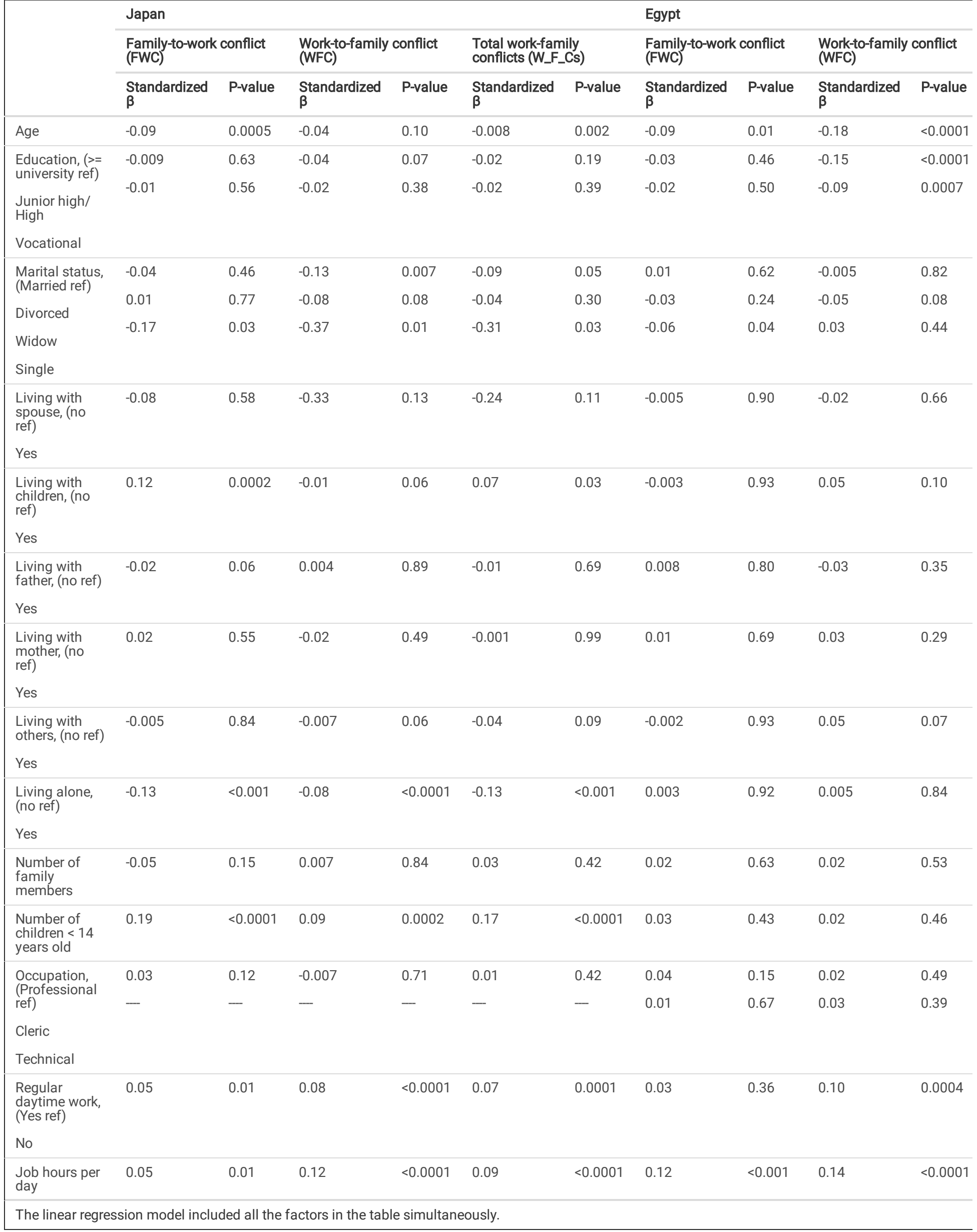




\begin{tabular}{|c|c|c|c|c|c|c|c|c|c|c|}
\hline & \multicolumn{6}{|l|}{ Japan } & \multicolumn{4}{|l|}{ Egypt } \\
\hline & \multicolumn{2}{|c|}{$\begin{array}{l}\text { Family-to-work conflict } \\
\text { (FWC) }\end{array}$} & \multicolumn{2}{|c|}{$\begin{array}{l}\text { Work-to-family conflict } \\
\text { (WFC) }\end{array}$} & \multicolumn{2}{|c|}{$\begin{array}{l}\text { Total work-family } \\
\text { conflicts (W_F_Cs) }\end{array}$} & \multicolumn{2}{|c|}{$\begin{array}{l}\text { Family-to-work conflict } \\
\text { (FWC) }\end{array}$} & \multicolumn{2}{|c|}{$\begin{array}{l}\text { Work-to-family conflict } \\
\text { (WFC) }\end{array}$} \\
\hline & $\begin{array}{l}\text { Standardized } \\
\beta\end{array}$ & P-value & $\begin{array}{l}\text { Standardized } \\
\beta\end{array}$ & P-value & $\begin{array}{l}\text { Standardized } \\
\boldsymbol{\beta}\end{array}$ & P-value & $\begin{array}{l}\text { Standardized } \\
\beta\end{array}$ & P-value & $\begin{array}{l}\text { Standardized } \\
\beta\end{array}$ & P-value \\
\hline $\begin{array}{l}\text { Time to reach } \\
\text { work }\end{array}$ & -0.003 & 0.87 & 0.04 & 0.02 & 0.02 & 0.25 & -0.002 & 0.92 & 0.06 & 0.01 \\
\hline $\begin{array}{l}\text { Working } \\
\text { overtime/extra } \\
\text { job (no ref) }\end{array}$ & 0.09 & $<0.0001$ & 0.24 & $<0.0001$ & 0.19 & $<0.0001$ & 0.17 & $<0.0001$ & 0.26 & $<0.0001$ \\
\hline Yes & & & & & & & & & & \\
\hline
\end{tabular}

The linear regression model included all the factors in the table simultaneously.

FWC

In Japanese women and men, living with children was positively associated, while living with a father or alone was inversely related to the FWC. The number of children in the family (standardized $\beta=0.21, p<0.001$ ) and living with others (standardized $\beta=-0.14, p=0.0008$ ) was related to the FWC in Japanese women. Meanwhile, overtime work in both women (standardized $\beta=0.06, p<0.04$ ) and men (standardized $\beta=0.09, p<0.001$ ), and job hours per day (standardized $\beta=$ $0.05, p=0.01$ ) and shiftwork (standardized $\beta=0.05, p=0.01$ ) in Japanese men were positively associated with the FWC.

On the other hand, working an extra job in Egyptian women (standardized $\beta=0.12, p=<0.0001$ ) and men (standardized $\beta=0.17, p=<0.0001$ ) was associated with the FWC. Junior high/high school education in reference to university education or more (standardized $\beta=-0.10, p=0.0007$ ) and living with other family members (standardized $\beta=0.05, p=0.03$ ) in women were associated with the FWC; while Job hours in men was related to the FWC (standardized $\beta=0.12, p=$ $<0.0001)$.

WFC

The regression coefficient of WFC for Japanese female clerics in reference to professionals was (standardized $\beta=-0.08, p=0.01$ ). Shift work, job hours per day, overtime work in Japanese women and men, and commuting time to work in Japanese men were associated with the WFC. Japanese women living with fathers had lower WFC. Single, divorced, and living alone Japanese men had lower WFC, while the standardized $\beta$ of Japanese men's WFC with the increasing number of family members was $0.84, p<0.03$.

The level of WFC in Egyptian women and men was positively correlated with shift work, job hours per day, working an extra job, and commuting time to work, while inversely associated with the education level. The standardized $\beta$ of the WFC in Egyptian female clerics in reference to professionals was $-0.06, p=0.02$.

Logistic regression for the association between the conflicts and self-reported health in Table 5 
Table 5

Odds ratio and $(95 \% \mathrm{Cls})$ for poor self-rated health in Japanese and Egyptian civil workers according to gender-and country-specific categories of work-family conflict

\begin{tabular}{|c|c|c|c|c|c|c|c|c|}
\hline & \multicolumn{4}{|l|}{ Japan } & \multicolumn{4}{|l|}{ Egypt } \\
\hline & Case/total & Model 1 & Model 2 & Model 3 & Case/total & Model 1 & Model 2 & Model 3 \\
\hline Women & $308 / 1596$ & & & & $273 / 1614$ & & & \\
\hline \multicolumn{9}{|c|}{$\begin{array}{l}\text { Family-to-work conflict } \\
\text { (FWC) }\end{array}$} \\
\hline Weak & $116 / 746$ & 1.00 & 1.00 & 1.00 & $95 / 690$ & 1.00 & 1.00 & 1.00 \\
\hline Fair & $115 / 611$ & $\begin{array}{l}1.49(1.08- \\
2.04)\end{array}$ & $\begin{array}{l}1.65(1.19- \\
2.28)\end{array}$ & $\begin{array}{l}1.61(1.16- \\
2.24)\end{array}$ & $121 / 717$ & $\begin{array}{l}1.32(0.98- \\
1.78)\end{array}$ & $\begin{array}{l}1.29(0.95- \\
1.74)\end{array}$ & $\begin{array}{l}1.30(0.96- \\
1.76)\end{array}$ \\
\hline Strong & $77 / 239$ & $\begin{array}{l}3.30(2.25- \\
4.86)\end{array}$ & $\begin{array}{l}4.14(2.70- \\
6.35)\end{array}$ & $\begin{array}{l}4.08(2.66- \\
6.27)\end{array}$ & $57 / 207$ & $\begin{array}{l}2.58(1.76- \\
3.78)\end{array}$ & $\begin{array}{l}2.54(1.71- \\
3.76)\end{array}$ & $\begin{array}{l}2.57(1.73- \\
3.82)\end{array}$ \\
\hline $\mathrm{p}$-trend & & $<0.0001$ & $<0.0001$ & $<0.0001$ & & $<0.0001$ & $<0.0001$ & $<0.0001$ \\
\hline \multicolumn{9}{|c|}{$\begin{array}{l}\text { Work-to-family conflict } \\
\text { (WFC) }\end{array}$} \\
\hline Weak & $67 / 562$ & 1.00 & 1.00 & 1.00 & $70 / 557$ & 1.00 & 1.00 & 1.00 \\
\hline Fair & $171 / 835$ & $\begin{array}{l}2.09(1.53- \\
2.87)\end{array}$ & $\begin{array}{l}2.22(1.60- \\
3.09)\end{array}$ & $\begin{array}{l}2.20(1.58- \\
3.07)\end{array}$ & $114 / 664$ & $\begin{array}{l}1.61(1.16- \\
2.23)\end{array}$ & $\begin{array}{l}1.59(1.13- \\
2.23)\end{array}$ & $\begin{array}{l}1.61(1.14- \\
2.26)\end{array}$ \\
\hline Strong & 70/199 & $\begin{array}{l}4.71(3.14- \\
7.08)\end{array}$ & $\begin{array}{l}5.33(3.41- \\
8.33)\end{array}$ & $\begin{array}{l}5.45(3.47- \\
8.54)\end{array}$ & $89 / 393$ & $\begin{array}{l}2.50(1.73- \\
3.59)\end{array}$ & $\begin{array}{l}2.61(1.78- \\
3.84)\end{array}$ & $\begin{array}{l}2.63(1.79- \\
3.88)\end{array}$ \\
\hline P-trend & & $<0.0001$ & $<0.0001$ & $<0.0001$ & & $<0.0001$ & $<0.0001$ & $<0.0001$ \\
\hline \multicolumn{9}{|c|}{$\begin{array}{l}\text { Total work-family conflicts } \\
\text { (W-F-Cs) }\end{array}$} \\
\hline Weak & $122 / 859$ & 1.00 & 1.00 & 1.00 & $101 / 752$ & 1.00 & 1.00 & 1.00 \\
\hline Fair & $92 / 447$ & $\begin{array}{l}1.89(1.37- \\
2.60)\end{array}$ & $\begin{array}{l}1.89(1.35- \\
2.64)\end{array}$ & $\begin{array}{l}1.88(1.34- \\
2.62)\end{array}$ & 77/479 & $\begin{array}{l}1.34(0.97- \\
1.86)\end{array}$ & $\begin{array}{l}1.36(0.97- \\
1.90)\end{array}$ & $\begin{array}{l}1.37(0.98- \\
1.92)\end{array}$ \\
\hline Strong & $94 / 290$ & $\begin{array}{l}3.74(2.63- \\
5.31)\end{array}$ & $\begin{array}{l}4.27(2.92- \\
6.26)\end{array}$ & $\begin{array}{l}4.28(2.91- \\
6.30)\end{array}$ & $95 / 383$ & $\begin{array}{l}2.44(1.76- \\
3.38)\end{array}$ & $\begin{array}{l}2.44(1.74- \\
3.42)\end{array}$ & $\begin{array}{l}2.46(1.75- \\
3.47)\end{array}$ \\
\hline $\mathrm{p}$-trend & & $<0.0001$ & $<0.0001$ & $<0.0001$ & & $<0.0001$ & $<0.0001$ & $<0.0001$ \\
\hline Men & $563 / 3266$ & & & & $83 / 1497$ & & & \\
\hline \multicolumn{9}{|c|}{$\begin{array}{l}\text { Family-to-work conflict } \\
\text { (FWC) }\end{array}$} \\
\hline Weak & $232 / 1874$ & 1.00 & 1.00 & 1.00 & $15 / 563$ & 1.00 & 1.00 & 1.00 \\
\hline Fair & $242 / 1137$ & $\begin{array}{l}2.31(1.88- \\
2.85)\end{array}$ & $\begin{array}{l}2.36(1.90- \\
2.93)\end{array}$ & $\begin{array}{l}2.38(1.91- \\
2.96)\end{array}$ & $32 / 592$ & $\begin{array}{l}2.29(1.21- \\
4.32)\end{array}$ & $\begin{array}{l}2.25(1.18- \\
4.29)\end{array}$ & $\begin{array}{l}2.33(1.21- \\
4.47)\end{array}$ \\
\hline Strong & $89 / 255$ & $\begin{array}{l}4.98(3.66- \\
6.77)\end{array}$ & $\begin{array}{l}4.99(3.61- \\
6.89)\end{array}$ & $\begin{array}{l}5.16(3.73- \\
7.15)\end{array}$ & $36 / 342$ & $\begin{array}{l}5.12(2.67- \\
9.81)\end{array}$ & $\begin{array}{l}4.98(2.50- \\
9.93)\end{array}$ & $\begin{array}{l}5.06(2.52- \\
10.17)\end{array}$ \\
\hline $\mathrm{p}$-trend & & $<0.0001$ & $<0.0001$ & $<0.0001$ & & $<0.0001$ & $<0.0001$ & $<0.0001$ \\
\hline \multicolumn{9}{|c|}{$\begin{array}{l}\text { Work-to-family conflict } \\
\text { (WFC) }\end{array}$} \\
\hline Weak & $143 / 1428$ & 1.00 & 1.00 & 1.00 & $36 / 773$ & 1.00 & 1.00 & 1.00 \\
\hline Fair & $310 / 1593$ & $\begin{array}{l}2.44(1.96- \\
3.03)\end{array}$ & $\begin{array}{l}2.37(1.89- \\
2.97)\end{array}$ & $\begin{array}{l}2.35(1.88- \\
2.95)\end{array}$ & $30 / 577$ & $\begin{array}{l}1.17(0.71- \\
1.93)\end{array}$ & $\begin{array}{l}1.12(0.67- \\
1.88)\end{array}$ & $\begin{array}{l}1.15(0.68- \\
1.94)\end{array}$ \\
\hline Strong & $110 / 245$ & $\begin{array}{l}8.84(6.45- \\
12.14)\end{array}$ & $\begin{array}{l}8.39(5.98- \\
11.81)\end{array}$ & $\begin{array}{l}8.45(6.01- \\
11.87)\end{array}$ & $17 / 147$ & $\begin{array}{l}2.86(1.55- \\
5.29)\end{array}$ & $\begin{array}{l}2.73(1.45- \\
5.15)\end{array}$ & $\begin{array}{l}2.77(1.45- \\
5.30)\end{array}$ \\
\hline P-trend & & $<0.0001$ & $<0.0001$ & $<0.0001$ & & 0.004 & 0.009 & 0.009 \\
\hline \multicolumn{9}{|c|}{$\begin{array}{l}\text { Total work-family conflicts } \\
\text { (W-F-Cs) }\end{array}$} \\
\hline Weak & $252 / 2103$ & 1.00 & 1.00 & 1.00 & $25 / 787$ & 1.00 & 1.00 & 1.00 \\
\hline \multicolumn{9}{|c|}{ Model 1: Adjusted for sociodemographic factors (age, education, occupation and marital status). } \\
\hline \multicolumn{9}{|c|}{$\begin{array}{l}\text { Model 2: Adjusted further for family factors (family structure, number of family members and the presence of family members below } 14 \text { years old), and } \\
\text { work factors (job hours per day, time to commute to work, shift work, working overtime or extra job). }\end{array}$} \\
\hline
\end{tabular}




\begin{tabular}{|c|c|c|c|c|c|c|c|c|}
\hline & \multicolumn{4}{|l|}{ Japan } & \multicolumn{4}{|l|}{ Egypt } \\
\hline & Case/total & Model 1 & Model 2 & Model 3 & Case/total & Model 1 & Model 2 & Model 3 \\
\hline Fair & $179 / 821$ & $\begin{array}{l}2.39(1.92- \\
2.98)\end{array}$ & $\begin{array}{l}2.37(1.89- \\
2.97)\end{array}$ & $\begin{array}{l}2.35(1.87- \\
2.95)\end{array}$ & $32 / 424$ & $\begin{array}{l}2.67(1.54- \\
4.60)\end{array}$ & $\begin{array}{l}2.53(1.45- \\
4.41)\end{array}$ & $\begin{array}{l}2.79(1.58- \\
4.92)\end{array}$ \\
\hline Strong & $132 / 342$ & $\begin{array}{l}5.98(4.57- \\
7.83)\end{array}$ & $\begin{array}{l}5.83(4.39- \\
7.76)\end{array}$ & $\begin{array}{l}6.01(4.50- \\
8.01)\end{array}$ & $26 / 286$ & $\begin{array}{l}3.31(1.85- \\
5.92)\end{array}$ & $\begin{array}{l}3.18(1.72- \\
5.86)\end{array}$ & $\begin{array}{l}3.11(1.67- \\
5.80)\end{array}$ \\
\hline P-trend & & $<0.0001$ & $<0.0001$ & $<0.0001$ & & $<0.0001$ & $<0.0001$ & $<0.0001$ \\
\hline \multicolumn{9}{|c|}{ Model 1: Adjusted for sociodemographic factors (age, education, occupation and marital status). } \\
\hline \multicolumn{9}{|c|}{$\begin{array}{l}\text { Model 2: Adjusted further for family factors (family structure, number of family members and the presence of family members below } 14 \text { years old), and } \\
\text { work factors (job hours per day, time to commute to work, shift work, working overtime or extra job). }\end{array}$} \\
\hline
\end{tabular}

We found dose-response positive associations between increasing total W_F_Cs and its two forms with poor self-reported health status in Japanese and Egyptian civil workers ( $p$-trend $<0.001)$. The multivariable ORs $(95 \% \mathrm{Cls}$ ) of poor health for the fair and strong categories of FWC, in reference to the weak category, were 1.61 (1.16-2.24) and 4.08 (2.66-6.27) in Japanese women, 1.30 (0.96-1.76) and 2.57 (1.73-3.82) in Egyptian women, 2.38 (1.91-2.96) and 5.16 (3.73-7.15) in Japanese men, and 2.33 (1.18-4.47) and 5.06 (2.52-10.17) in Egyptian men. The respective ORs (95\% Cls) for the fair and strong categories of WFC, in reference to the weak category, were 2.20 (1.58-3.07) and 4.45 (3.47-8.54) in Japanese women, 1.61 (1.14-2.26) and 2.63 (1.79-3.88) in Egyptian women, 2.35 (1.88-2.95) and 8.45 (6.01-11.87) in Japanese men, and 1.15 (0.68-1.94) and 2.77 (1.45-5.30) in Egyptian men.

\section{Discussion}

In this large cross-cultural study, we compared the prevalence of W_F_Cs and its two forms FWC and WFC, factors associated with each form of conflict, and the association of these conflicts with the poor self-rated health status among Japanese and Egyptian civil workers. A higher prevalence of the conflicts was evident in Egyptians than Japanese (except for a higher prevalence of FWC in Japanese than Egyptian women), while a higher prevalence of poor self-rated health was estimated for Japanese than Egyptian civil workers of both genders. Work environment, family size, and being single was associated with the conflicts score in both countries. On the other hand, cohabitants in Japan and education in Egypt were associated with conflicts between work and family. For both genders in both countries, the odds for rating one's physical health status as poor was strongly related to the level of FWC, WFC, and total W_F_Cs. Even with longer working and commuting time in Japanese civil workers, their lower W_F_Cs score may imply a difference in family function's ideal or cultural expectation.

\section{The prevalence and correlates of W_F_Cs}

A previous study conducted among 1021 Egyptian community dwellers revealed that $46.7 \%$ had high WFC, and 50.8\% had high FWC [11]. Burke and El-Kot found higher mean W_F_Cs (=3.0) in 242 (146 males and 96 females) Egyptian managers than that in the US (=2.6) [16]. Kobayash et al reported the prevalence of high WFC and FWC among Japanese residents as $36.6 \%$ and $36.4 \%$ in men and $28.4 \%$ and $56.8 \%$ in women [8]. The prevalence of W_F_Cs estimated by Koura et al was much higher; $54.0 \%$ in 1258 male and $72.5 \%$ in 550 female civil servants on the west coast of Japan [12]. In contrast, Shimazu et al reported lower WFC and FWC prevalence of $15.2 \%$ and $21.2 \%$ in male and $22.5 \%$ and $16.3 \%$ in female Japanese dual-earner couples with preschool children [17]. The estimated prevalence in other working populations varied largely by culture, study design, and conflicts' diagnostic tool. Still, it was, in general, comparable to our estimated prevalence and indicative of the higher prevalence in women than men. Lallukka et al estimated it as $17 \%, 18 \%, 19 \%$ in male and $22 \%, 19 \%$, and $20 \%$ in female British, Finnish, and Japanese civil employees [5]. The prevalence of high W_F_Cs was $18 \%$ and $24 \%$ among full-time employed European men and women according to the European Working Conditions Survey 2015 [21]. Griep et al reported a prevalence of $16.0 \%$ for WFC and $7.5 \%$ for FWC among Brazilian men and $25.0 \%$ and $6.8 \%$ among Brazilian women [26].

Byron suggested that work-related factors are more associated with WFC than FWC, while some family factors are associated more with FWC than WFC [3]. The work-related factors in our study were associated, in both countries, with the WFC in both genders. This result was consistent with previous studies that working longer, overtime, and shift work [14-16, 18] representing high job demands and low job control [27] were positively associated with WFC. The workload could have negative consequences for workers who struggle to balance the demands of work and family roles.

On the other side, the family structure affected the Japanese civil workers' perception of FWC. The results match previous findings in Japan [14, 15, 18] and Europe $[28,29]$. Living with children adds significantly to FWC, and the effect is more substantial when the children are in the youngest age group. Similar to our results, Fujimura et a/ reported an increased odds of FWC among Japanese civil servants living with children; OR=1.65, 95\%Cl: 1.33-2.05, and a decreased odds of FWC among those living with parents; OR= 0.86, 95\%Cl: 0.71-1.04 [18]. The null association between cohabitants and W_F_Cs in the Egyptian civil

Page 13/16 
workers might be attributed to the high proportion of Egyptians living in multigeneration families in the same household; thus, the load of children in the family could be compensated by the presence of grandparents [30]. An interesting finding was that living with other family members was inversely associated with the Japanese women's but positively associated with the Egyptian women's FWC. As polygyny is allowed in Egypt, it paved the way for jealousy and conflict when other family members in Egyptian women's lives include co-wife, stepchildren, and co-sister-in-law [31], and might explain the positive association with the FWC.

Findings among Egyptian civil workers agreed with those from other working populations, where Griep et al in Brazil [26] and Carnicer et al in Spain [28] found higher education related to higher WFC. Highly educated subjects are expected to attain higher rank jobs with greater job demands, competitive edge, and expectations. The majority of civil workers in the Japanese cohort were educated to high levels (only $5.8 \%$ were junior high or high school graduates); this might explain why education did not show such association among the Japanese civil workers.

\section{The reported self-related health status and its associations with W_F_Cs in both countries:}

Similar to our findings, the previous studies indicated a higher prevalence of poor self-rated health in Japanese; $13.9 \%$ in men and $17.7 \%$ in women [8], $35.2 \%$ in men and $36.0 \%$ in women [12] than Egyptians; $16.9 \%$ [11].

Despite the observed gender difference in the prevalence of W_F_Cs (Egypt: 19.1\% in men vs. 23.7\% in women, Japan:10.5\% in men and 18.2\% in women) and poor self-rated health (Egypt: $5.5 \%$ in men vs. $16.9 \%$ in women, Japan: $17.2 \%$ in men vs. $19.3 \%$ in women), our results are in line with the previous research showing associations of W_F_Cs and its two forms WFC and FWC with poor self-rated health of both genders in Japan [8, 12, 20], Egypt [11], and other populations $[4,19,21,26]$. Increased inter-role conflicts between work and family domains can reduce the time for sleep [25] or leisure activities, thus increasing psychological stress [9] and affecting the physical health conditions [3].

\section{Strengths And Limitations}

The present study has several strengths and limitations. Thanks to the relatively large sample of recruited Egyptian and Japanese civil workers, there was no problem with the statistical power for the gender- and country-specific analyses in the current study. Also, the participants were working in a wide range of public occupational sectors, rather than one-company samples. In addition, we did not assess the targeted variable (W_F_Cs) via a simple question; to the contrary, we used an expanded validated questionnaire that was widely used internationally and in both populations. Regarding the limitations, the crosssectional design, the convenience sampling, and the self-reported data could have introduced some sorts of time-lead, selection, and misclassification bias. Thus, the causal inference and the generalizability of the results to the whole working population; nevertheless, those in the private enterprise are not possible.

\section{Conclusions}

The prevalence and the factors related to W_F_Cs and self-rated health varied by gender among the Japanese and Egyptian civil workers. However, the robust associations between W_F_Cs and poor self-rated health were evident for both countries' civil workers of both genders. Our findings suggest that governmental measures are required to improve the working environment of both the Japanese and Egyptian civil workers to prevent work-family role conflicts from adding to their risk of poor health status. More family social interactions are suggested to the Japanese workers. While more flexible work arrangements should be targeting the highly-educated Egyptian civil workers.

\section{Declarations}

Ethics approval: According to the declaration of Helsinki, the ethical review board in Osaka University has also approved this cross-cultural study (approval no 19501).

Consent to participate: All participants provided written informed consent.

Consent for publication: Not applicable.

Availability of data and material: Data are available upon reasonable request to the corresponding author.

Competing interests: None for all authors.

Funding: This study was supported by the Japan Society for Promotion of Science (JSPS) fund, grant-in-aid for basic research C general no 19K10621 (20192022) to ESE and $18 \mathrm{H} 03057$ to HY, Health and Labor Sciences research grants for Comprehensive Research on Cardiovascular and Life-Style Related Diseases (H29-Junkankitou [Seishuu]-Ippan-003) from the Ministry of Health, Labor and Welfare to HY.

Authors' contribution: For the Egyptian survey, AOK, EES, MEM, IH, YH, MES, GER, BS, ESA, and HEE participated in data curation, investigation, and acquisition. For the Japanese data, $\mathrm{YH}$ participated in data curation, investigation, and acquisition. $\mathrm{EES}, \mathrm{IH}, \mathrm{YH}$, and BS participated in fund acquisition and research design. EES analyzed the data. EES, AOK, and HEE drafted the manuscript. MEM, IH, YH, MES, GER, BS, ESA, and EAS provided a critical review of the research article.

Acknowledgments: We thank the Japan Society for the Promotion of Science (JSPS) for providing the research grant for this comparative study. Our deep gratitude to the participants and the healthcare personnel of the Aichi prefecture local government office and the Public Health Department, Faculty of Medicine, Minia University staff, specifically Drs. Maggi M. Ayad, Shaimaa M Ahmed, Nehal R Raouf, Amany M Reda, Chrestina M Fekry, Shaza F Mohamed, Sara M Sayed, Asmaa M Taha, Yasmine N Gaballah, Hager A Zaki. We also thank our colleagues from Osaka University Center of Medical Data Science, Advanced Clinical Epidemiology Investigator's Research Project, for providing their insight and expertise for our research.

Page 14/16 
Authors ORCID: Abd El Latif OK 0000-0002-9957-3348, Eshak ES 0000-0002-3564-1938, Mahfouz EM 0000-0001-7146-9808, Iso H 0000-0002-9241-7289, Yatsuya H 0000-0002-6220-9251, Mohamed ES 0000-0003-1231-9484, Ghazawy ER 0000-0002-3807-6954, Baba S 0000-0002-6213-8115, Emam SA 00000001-9232-4501, Elkhateeb ASa 0000-0002-6553-0649, Hassan EE 0000-0002-3559-0253.

\section{References}

1. - Greenhaus JH, Beutell NJ. Sources of conflict between work and family roles. Academy of Management Review.1985;10:76-88. https://doi.org/10.2307/258214

2. - Scott LB, Carl PM, Donald CM, Jon CC. The impact of work/family demand on work-family conflict. Journal of Managerial Psychology. 2008; 23(3): 215-235. https://doi.org/10.1108/02683940810861356

3. - Bryon K. A meta-analytic review of work-family conflict and its antecedents. J Vocat Behav. 2005; 67(2):169-98. https://doi.org/10.1016/j.jvb.2004.08.009

4. - van Hooff ML, Geurts SA, Taris TW, Kompier MA, Dikkers JS, Houtman IL, van den Heuvel FM. Disentangling the causal relationships between workhome interference and employee health. Scand J Work Environ Health. 2005;31(1):15-29. doi: 10.5271/sjweh.844.

5. - Lallukka T, Chandola T, Roos E, Cable N, Sekine M, Kagamimori S, Tatsuse T, Marmot M, Lahelma E. Work-family conflicts and health behaviors among British, Finnish, and Japanese employees. Int J Behav Med. 2010;17(2):134-42. doi: 10.1007/s12529-009-9050-8.

6. - Kahn RL, Wolfe DM, Quinn RP, Snoek JD, Rosenthal RA. Organizational stress: Studies in role conflict and ambiguity. NewYork, John Wiley.1964.

7. - Malik MS, Awan AG, UI-Ain Q. Role of work family conflict on organizational commitment and organizational effectiveness. Arab J Bus Manag Rev.2015; 3(1):115-126.

8. - Kobayashi T, Honjo K, Eshak ES, Iso H, Sawada N, Tsugane S; Japan Public Health Center-based Prospective Study for the Next Generation (JPHC-NEXT) Study Group. Work-family conflict and self-rated health among Japanese workers: How household income modifies associations. PLoS One. 2017;12(2):e0169903. doi: 10.1371/journal.pone.0169903.

9. - Eshak ES. Mental health disorders and their relationship with work-family conflict in Upper Egypt. Journal of Family and Economic Issues. 2019a;40(4):623-632. doi: 10.1007/s10834-019-09633-3.

10. - Scott LB, Carl PM, Allison WP. The effects of work-family conflict and family-work conflict on nonattendance behaviors. Journal of Business Research. 2005;58(7):919-925.

11. - Eshak ES, Kamal NN, Seedhom AE, Kamal NN. Work-family conflict and self-rated health among dwellers in Minia, Egypt: Financial strain vs social support. Public Health. 2018;157:69-76. doi: 10.1016/j.puhe.2018.01.016.

12. - Koura U, Sekine M, Yamada M, Tatsuse T. The health effects of work-family conflict in men and women Japanese civil servants: a longitudinal study. Ind Health. 2020;58(5):423-432. doi: 10.2486/indhealth.2019-0189.

13. - de Bruin A, Picavet HS, Nossikov A. Health interview surveys. Towards international harmonization of methods and instruments. WHO Reg Publ Eur Ser. 1996;58:i-xiii, 1-161.

14. - Watai I, Nishikido N, Murashima S. Gender difference in work-family conflict among Japanese information technology engineers with preschool children. J Occup Health. 2008;50(4):317-27. doi: 10.1539/joh.17124.

15. - Kato M, Yamazaki Y. An examination of factors related to work-to-family conflict among employed men and women in Japan. J Occup Health. 2009;51(4):303-13. doi: 10.1539/joh.18099.

16. - Burke R, El-Kot G. Correlates of work-family conflicts among managers in Egypt. International Journal of Islamic and Middle Eastern Finance and Management.2010;3(2):113-131.

17. - Shimazu A, Kubota K, Bakker A, Demerouti E, Shimada K, Kawakami N. Work-to-family conflict and family-to-work conflict among Japanese dual-earner couples with preschool children: a spillover-crossover perspective. J Occup Health. 2013;55(4):234-43. doi: 10.1539/joh.12-0252-oa.

18. - Fujimura Y, Sekine M, Tatsuse T. Sex differences in factors contributing to family-to-work and work-to-family conflict in Japanese civil servants. J Occup Health. 2014;56(6):485-97. doi: 10.1539/joh.14-0045-OA.

19. - Winter T, Roos E, Rahkonen O, Martikainen P, Lahelma E. Work-family conflicts and self-rated health among middle-aged municipal employees in Finland. Int J Behav Med. 2006;13(4):276-85. doi: 10.1207/s15327558ijbm1304_2.

20. - Sekine M, Chandola T, Martikainen P, Marmot M, Kagamimori S. Sex differences in physical and mental functioning of Japanese civil servants: explanations from work and family characteristics. Soc Sci Med. 2010;71(12):2091-9. doi: 10.1016/j.socscimed.2010.09.031.

21. - Borgmann LS, Kroll LE, Müters S, Rattay P, Lampert T. Work-family conflict, self-reported general health and work-family reconciliation policies in Europe: Results from the European Working Conditions Survey 2015. SSM Popul Health. 2019;9:100465. doi: 10.1016/j.ssmph.2019.100465.

22. - Li Y, Yatsuya H, Hanibuchi T, Hirakawa Y, Ota A, Uemura M, Chiang C, Otsuka R, Murata C, Tamakoshi K, Toyoshima H, Aoyama A. The association between objective measures of residence and worksite neighborhood environment, and self-reported leisure-time physical activities: The Aichi Workers' Cohort Study. Prev Med Rep. 2018;11:282-289. doi: 10.1016/j.pmedr.2018.07.007.

23. - Eshak ES, Elkhateeb AS, Abdellatif OK, Hassan EE, Mohamed ES, Ghazawy ER, Emam SA, Mahfouz EM. Antecedents of work-family conflict among Egyptian civil workers. Z Gesundh Wiss. 2021:1-10. doi: 10.1007/s10389-021-01641-8.

24. - Grzywacz JG, Marks NF. Reconceptualizing the work-family interface: an ecological perspective on the correlates of positive and negative spillover between work and family. J Occup Health Psychol. 2000;5(1):111-26. doi: 10.1037//1076-8998.5.1.111. 
25. - Eshak ES. Work-to-family conflict rather than family-to-work conflict is more strongly associated with sleep disorders in Upper Egypt. Ind Health. 2019b;57(3):351-358. doi: 10.2486/indhealth.2018-0091.

26. - Griep RH, Toivanen S, van Diepen C, Guimarães JMN, Camelo LV, Juvanhol LL, Aquino EM, Chor D. Work-Family Conflict and Self-Rated Health: the Role of Gender and Educational Level. Baseline Data from the Brazilian Longitudinal Study of Adult Health (ELSA-Brasil). Int J Behav Med. 2016;23(3):372382. doi: 10.1007/s12529-015-9523-x.

27. - Bulter AB, Grzywacz JG, Bass BL, Linney KD. Extending the demands-control model: A daily studyof job characteristics, work-family conflict and workfamily facilitation. J Occup Organi Pshychol. 2005; 78:155-69. https://doi.org/10.1348/096317905X40097

28. - Carnicer MPdL, Sánchez AM, Pérez MP, Jiménez MJV. Work-family conflict in a southern European country: The influence of job-related and non-related factors", Journal of Managerial Psychology.2004;19 (5):466-48. https://doi.org/10.1108/02683940410543579

29. - Remery C, Schippers J. Work-Family Conflict in the European Union: The Impact of Organizational and Public Facilities. Int J Environ Res Public Health. 2019;16(22):4419. doi: 10.3390/ijerph16224419.

30. - Okasha T, Elkholy H, El-Gamry R. Overview of the family structure in Egypt and its relation to psychiatry. International Review Psychiatry. 2012;24 (2):162-165. doi: 10.3109/09540261.2012.658030.

31. - Essien DE. The interplay between conflict and solidarity in co-wife family relationship:Experience from Africa. International Journal of Development and Sustainability. 2018;7(4): 1544-163.

\section{Supplementary Files}

This is a list of supplementary files associated with this preprint. Click to download.

- SupplementalTable1.docx 